\title{
Os rappers e o 'rap consciência': novos agentes e instrumentos na luta anti-racismo no Brasil na década de 1990
}

\author{
Sales Augusto dos Santos \\ Doutor em Sociologia pela Universidade de Brasília \\ Pesquisador associado do Núcleo de Estudos Afro-Brasileiros da UnB \\ salesaugustodossantos@gmail.com
}

Uma das mudanças que foi importante em termos de mobilização negra contra o racismo no Brasil na década de 1990 foi a reutilização da música, por meio do rap, como forma de denunciar e condenar a opressão racial brasileira. Neste artigo se verá como uma parte importante dos afro-brasileiros, os rappers, que até então não participava diretamente da luta anti-racista, passou a fazer coro com os movimentos sociais negros clássicos, engajando-se no combate contra o racismo, ao utilizar a sua música como instrumento de luta contra o racismo.
\end{abstract}

Palavras-chave: rap; rappers; anti-racismo; movimentos sociais negros.

\section{Introdução}

$\mathrm{H}$ Á VÁRIOS TIPOS DE MOVIMENTOS SOCIAIS NEgROS e também vários tipos de luta contra o racismo na sociedade brasileira (Santos, 2007). Assim, por uma questão didática, designaremos movimentos sociais negros clássicos os movimentos sociais negros anteriores à década de 1990, para distingui-los das novas formas de movimentos sociais negros que emergiram no início dos anos 1990, tais como os cantores do Rap Consciência, as ONGs de cunho racial, os parlamentares negros e a militância negro-intelectual nas universidades, entre outras formas de luta contra o racismo e a desigualdade racial brasileira.

Conforme Santos (2007), a luta afro-brasileira clássica (os movimentos sociais negros clássicos) contra o racismo produziu outros frutos (ou agentes) de e para a própria militância e luta negra contra o racismo, que começaram a emergir especialmente na última década do século XX. Agentes e formas de luta que os próprios movimentos negros clássicos passam a perceber e reconhecer como importantes para o fortalecimento das antigas organizações negras e, especialmente, para o crescimento da luta pelo fim do racismo e pela igualdade racial no Brasil. Conforme o documento da Marcha Contra o Racismo, pela Cidadania e a Vida, realizada em 20 de novembro de 1995, pelos movimentos negros brasileiros, 
A temática racial, particularmente neste ano do Tricentenário de Zumbi, destaca-se de forma vigorosa no espaço brasileiro de discussão pública. 'Isto como fruto do crescimento, sem precedentes em nossa história, da luta contra o racismo'. Esta é uma das vitórias resultantes tanto do fortalecimento das organizações do movimento negro, quanto da multiplicação e interiorização das entidades. 'As novas formas de articulação e de expressão da militância' nos locais de trabalho, no campo, nos sindicatos, nos movimentos populares, partidos, universidades, parlamento, nas entidades religiosas, órgãos governamentais etc., 'vêm nos últimos anos acrescentando melhores armas no combate ao racismo'. Há de se destacar ainda, nessa empreitada, a emergência do movimento de mulheres negras, com fisionomia própria e caráter nacional, que duplamente luta contra a opressão racial e de gênero (Enmz, 1996, p. 9 , grifo nosso).

O fato é que os movimentos sociais negros clássicos, mesmo com a sua retração, conforme Andrews $(1991)^{1}$, conseguiram disseminar direta e indiretamente uma consciência crítica ante as relações raciais brasileiras e as desigualdades entre negros e brancos. E isso ocorreu não somente entre uma parte dos afrobrasileiros em ascensão social, visto que esses sentiam (e ainda sentem) mais duramente o peso da discriminação racial (Andrews, 1998; Moura, 1994; Hasenbalg, 1979), mas também entre trabalhadores ou desempregados, estudantes, entre outros grupos sociais, que vivem especialmente nas grandes metrópoles brasileiras e, em especial, os que habitam suas periferias.

Dito de outra maneira, assim como o racismo é dinâmico, se renova e se reestrutura de acordo com a evolução ou transformação da sociedade e das conjunturas históricas (Munanga, 1994, p. 178), a luta contra o racismo também não é estática. Novos sujeitos e agentes sociais passam a combater o racismo, bem como novas formas de articulação e de expressão da militância negra emergem nesse período, ajudando a disseminar o discurso anti-racismo e pró-igualdade racial, como, por exemplo, os negros intelectuais, as ONGs de cunho racial, os parlamentares negros e os rappers do Rap Consciência, conforme demonstrou o sociólogo Santos (2007). É sobre estes últimos agentes anti-racistas, os rappers do Rap Consciência, e seu instrumento de luta anti-racismo, a música rap, que trata o presente artigo.

\section{Rap e rappers: novos sujeitos e instrumentos do discurso anti-racismo}

Uma das mudanças que foi importante em termos de mobilização negra contra o racismo no Brasil na década de 1990 foi a reutilização da música, por meio do rap, como forma de denunciar e condenar a opressão racial brasileira. Se, por um lado, o clamor e reivindicação de entidades negras como, por exemplo, o Movimento Negro Unificado (MNU), por igualdade racial de direito e de fato, nas décadas anteriores à década de 1990, não conseguiram sensibilizar efetivamente a esfera pública brasileira para a necessidade de incluir a questão racial na agenda nacional (Santos, 2007), por outro lado, e até mesmo em função disso, uma parte importante dos afro-brasileiros, que até então não participava diretamente da luta anti-racista, passou a fazer coro com os movimentos sociais negros clássicos, engajando-se no combate contra o racismo.

Jovens afro-brasileiros das periferias dos grandes centros urbanos, especialmente de São Paulo, Brasília, Belo Horizonte e Goiânia (Amorin, 1997), passaram a cantar/relatar, por meio de uma música reflexiva e extremamente crítica, as violências racial e social a que estão submetidos os moradores das periferias dos grandes centros urbanos brasileiros, traduzindo-as em versos por meio de uma poesia extraordinariamente contundente, o rap.

Uma vez que os movimentos sociais negros clássicos não conseguiram conquistar aliados incondicionais na luta contra o racismo antes da década de 1990, ou seja, uma vez que os canais tradicionais de contestação e os participantes da esfera pública brasileira, como os partidos políticos, os sindicatos de trabalhadores e empresários, entre outros, se recusavam a incluir a questão racial na agenda nacional, e, mais do que isso, a propor soluções concretas e viáveis contra o racismo e a desigualdade racial, os setores mais oprimidos pela discriminação racial no Brasil insurgiram-se, por meio da música, entre outras formas de luta anti-racista, contra a estratégia ou consenso do silêncio no que tange à questão racial e apresentaram a música por meio do Rap como uma nova forma de luta negra ou dos movimentos sociais negros nos anos 1990. Assim, passaram a utilizar o rap como um veículo de comu-

1 Em realidade, esta afirmação de Andrews (1991), do refluxo dos movimentos sociais negros, precisa ser verificada por meio de pesquisas mais amplas, mais complexas e mais sofisticadas. Há pelo menos uma informação que indica o crescimento das entidades dos movimentos sociais negros depois da década de 1980. Se a pesquisa realizada por Caetana Damasceno et al., entre os anos de 1986 e 1987, publicada no Catálogo de Entidades de Movimento Negro no Brasil (1988), demonstrou que havia 573 (quinhentos e setenta e três) entidades negras no Brasil, o professor Hélio Santos afirmou que "o banco de dados desenvolvido pelo Núcleo de Estudos Interdisciplinares do Negro Brasileiro (NEINB-USP) cadastrou mais de 1.300 (mil e trezentas) entidades do movimento negro, no qual se destacam as de cunho cultural, recreativo, religioso e político. Tais entidades, quando não atuam diretamente no enfrentamento das desigualdades raciais, operam na linha da resistência cultural, o que, indiretamente, reforça o conjunto da luta" (Santos, 2000, p. 70). 
nicação e denúncia contra a discriminação de raça e de classe ${ }^{2}$ no Brasil.

O grupo que mais se destacou nesse processo, em nível nacional, foi o Racionais MC's. Logo na introdução do disco Raio X do Brasil ${ }^{3}$, os Racionais afirmava que a liberdade de expressão, por meio da música, era um dos poucos direitos que o 'jovem negro' ainda tinha no Brasil. Conforme os Racionais,

\section{Introdução ao CD Raio X do Brasil}

\section{3}

Fodidamente voltando

\section{Racionais}

Usando e abusando da nossa liberdade de expressão

Um dos poucos direitos que o jovem negro ainda tem nesse país

Você está entrando no mundo da informação

Auto-conhecimento

Denúncia e diversão

Esse é o raio X do Brasil

Seja bem-vindo.

O 'raio X do Brasil', para os Racionais ${ }^{4}$, é uma denúncia contundente da opressão contra um dos grupos sociais mais vulneráveis do país: os pobres das periferias dos grandes centros urbanos, que são majoritariamente afro-brasileiros ou, se quiser, negros. À primeira vista, os Racionais e demais grupos de Rap Consciência apresentam um discurso que literalmente prega a necessidade de os 'manos' recusarem todas as violências diárias que o 'sistema' (o centro do sistema) impõe à periferia. Em certo sentido, é um discurso moralizador, que condena o uso de drogas (incluindo o álcool), a 'treta', a malandragem, entre outras coisas destrutivas na e para a periferia. Como os próprios rappers afirmam, eles buscam passar 'uma mensagem positiva' para os 'manos'. Porém, é também um discurso constante de raça e classe, que estabelece uma recorrente oposição entre o mundo dos negros e o mundo dos brancos (Fernandes, 1972), entre pobres e ricos, periferia e centro. Portanto, se à primeira vista o discurso das letras expressa uma mensagem pacificadora ou, conforme afirma a antropóloga Amorim (1997, p. 106), os grupos de rap 'cantam a união e a paz em suas rimas', não podemos deixar de perceber que essa mensagem é pacifista internamente - para a própria periferia; mas é de contraposição e, simultaneamente, agressão ao sistema. Conforme as músicas abaixo $^{5}$,

\section{Fim de Semana no Parque}

A toda comunidade pobre da Zona Sul

Chegou fim de semana todos querem diversão

Só alegria, nós estamos no verão

Mês de janeiro

São Paulo, Zona Sul

Todo mundo acordado, calor, céu azul

Eu quero aproveitar o sol

Encontrar uns camaradas pro basquetebol

Provavelmente correndo pra lá e pra cá

Jogando bola

Descalços nas ruas de terra

É, brincam do jeito que dá

\section{Hey Boy}

Hey boy, o que você está fazendo aqui

Meu bairro não é o seu lugar e você vai se ferir

Você não sabe onde está

E caiu num ninho de cobras

Eu acho que você vai ter que se explicar

Pra sair não vai ser fácil

A vida aqui é dura

Dura é a lei do mais forte

Onde a miséria não tem cura

E o remédio mais provável é a morte

Continuar vivo é uma batalha

Isso é

Se eu não cometer falhas

2 Analisando as letras dos rappers brasileiros, ou melhor, daqueles que produzem o chamado Rap Consciência, percebe-se explicitamente um discurso de raça e classe. Rap Consciência, segundo a antropóloga Lara dos Santos Amorim, "trata-se do rap propriamente dito quando se diferenciou do funk, referindo-se mais especificamente aos conteúdos das letras que procuram denunciar a exclusão social e o racismo" (Amorim, 1997, p. 108). Neste artigo, enfatizaremos mais o discurso de raça, em função dos objetivos deste paper. Isso não implica negarmos o discurso classista, mas priorizarmos apenas o forte discurso racialista dos grupos de Rap Consciência, em face do racismo praticado contra os negros. Mais do que isso, não pretendemos fazer uma análise de discurso das letras. Faremos alguns poucos comentários sobre as letras e deixaremos que elas falem por si mesmas. Ou seja, que os interpretadores (nós) não coloquem palavras nas bocas dos interpretados. Porém, como afirma Pinho (2001) "isso não significa renúncia à responsabilidade interpretativa, mas em renunciar à pretensão elucidatória, que é em última instância a reprodução de um princípio de autoridade".

3 Lançado no final de 1993, "com festa de lançamento na quadra da Rosa de Ouro (escola de samba da cidade de São Paulo) com mais de 10.000 pessoas", segundo o próprio encarte do CD

4 Este "raio X do Brasil" não é só para o Racionais, mas para praticamente todos os grupos de Rap Consciência.

5 As letras de rap são enormes e geralmente não constam dos encartes dos CDs. 
Gritando palavrão. É do jeito deles

Eles não têm videogames

Às vezes nem televisão

Mas todos eles contam com São Cosme e São Damião

A única proteção

No último natal

Papel Noel escondeu um brinquedo prateado

Brilhava no meio do mato

Um menininho de dez anos achou um presente

Era ferro com doze balas no pente

E o fim-de-ano foi melhor pra muita gente

Eles também gostariam de ter bicicleta

De ver seu pai fazendo cooper, tipo atleta

Gostam de ir ao parque e se divertir e que alguém os ensinasse a dirigir

Mas eles são canibais e mesmo assim é um sonho

Fim-de-semana no Parque Santo Antônio

Fim-de-semana no Parque

Olha só aquele clube que é da hora

Olha aquela quadra

Olha aquele campo, olha

Olha quanta gente, tem sorveteria, cinema, piscina quente

Olha quanto boy, olha quanta mina (afoga essa vaca dentro da piscina).

Tem corrida de Kart, dá pra ver. É igualzinho ao que eu vi ontem na TV

Olha só aquele clube que é da hora

Olha só aquele pretinho vendo tudo do lado de fora

Nem se lembra do dinheiro que tem que levar pro seu pai

Bem louco gritando dentro de um bar

Nem se lembra de ontem

De onde o futuro

Ele apenas sonha através do muro

Milhares de casa amontoadas

Ruas de terra

Esse o morro

A minha área me espera

Gritaria na feira

Vamos chegando

Eu gosto disso: mais calor humano

Na periferia a alegria é igual

É quase meio-dia, a euforia é geral

E lá que moram meus irmãos, meus amigos

E a maioria por aqui se parece comigo

E eu também sou o bam-bam-bam e o que manda

E o pessoal desde as dez da manhã está no samba

Preste atenção no repique, atenção no acorde

"Como é que é Mano Brown?"

A n 1 em baixa renda da cidade, comunidade Zona Sul

É dignidade

Tem um corpo no escadão

A tiazinha desce o morro

Polícia: a morte. Polícia: Socorro!

Aqui não vejo nenhum clube poliesportivo

Pra moleca freqüentar, nem um incentivo

O investimento no lazer é muito escasso,
E se eu não fosse esperto tirariam tudo de mim

Arrancavam minha pele, minha vida, enfim

Tenho que me desdobrar pra não puxarem meu tapete

Estar sempre quente

Pra não ser surpreendido de repente

Se eu vacilo

Trancam minha vaga

O que você fizer aqui mesmo você paga

A pouca grana que eu tenho não dá pro próprio consumo

A marginalidade cresce sem precedência

Conforme o tempo passa, aumenta

É a tendência

E muitas vezes não tem jeito

A solução é roubar

E seus pais acham que a cadeia é o nosso lugar

O sistema é a causa e nós somos a conseqüência maior

da chamada violência

Porque na real

Com a nossa vida ninguém se importa

E ainda querem que sejamos patriotas

Hey boy ...

Isso tudo é verdade

Mas não tenha dó de mim

Porque esse é o meu lugar

E eu o quero mesmo assim

Mesmo sendo o lado esquecido da cidade

E bode expiatório de toda e qualquer mediocridade

A sociedade já não sabe o que fazer

Se vão interferir ou deixar acontecer

Mas por sermos todos pobres

Os tachados somos nós

Só por ser conveniente

Hey boy ...

Pense bem se não faz sentido

Se hoje em dia eu fosse um cara tão bem sucedido

Como você é chamado de superior

Tem todos na mão e tudo a seu favor

Sempre teve tudo e não fez nada por ninguém

Se as coisas andam mal é sua culpa também

Seus pais dão as costas pra o mundo que os cerca

Ficam com o maior, melhor, pra nós nada resta

Você gasta fortuna se vestindo de etiqueta

E na sarjeta crianças, futuros homens

Quase não comem, morrem de fome

Com frio e com medo, já não é segredo

(inaudível) só me dê razão, não fale mais nada, que vai ser em vão

Hey boy ...

Você faz parte daqueles que colaboram para que

A vida de muitas pessoas seja tão ruim

Acha que sozinha não vai mudar

Mas é por muitos pensarem assim como você

Que situação

Vai de mal a pior 
O centro comunitário é um fracasso

Mas aí, se quiser se destruir está no lugar certo

Tem bebida e cocaína sempre por perto

A cada esquina

100, 200 metros

Nem sempre é bom ser esperto

Shimdt, Ítalo Rossi, Dreher, Campari

Pronúncia agradável, estrago imediato

Nomes estrangeiros que estão no nosso meio pra m-a-t-a-r

Como se fosse ontem, ainda me lembro

Sete horas, Sábado, quatro de dezembro

Uma bala, uma moto, com dois imbecis, mataram nosso mano que fazia o morro feliz

E indiretamente ainda faz

Mano Rogério, esteja em paz

Vigiando lá de cima

A molecada do Parque Regina

Fim-de-semana no parque

Tô cansado dessa porra!

De toda essa bobagem

Alcoolismo, vingança, treta, malandragem

Mãe angustiada, filho problemático, famílias destruí-

das, fim-de-semana trágico

$\mathrm{O}$ sistema quer isso, a molecada tem que aprender

Fim-de-semana no Parque Ipê

Fim-de-semana no parque

\author{
E como sempre \\ Você pensa em si só \\ Só egoísmo, ambição e desprezo \\ Serão os argumentos pra matar você mesmo \\ Então eu digo \\ Hey Boy ... \\ Não fique surpreso se um ridículo e odioso \\ Círculo vicioso
}

Sistema que você faz parte me transformar num criminoso

E doloroso será ser rejeitado, humilhado

Considerado um marginal, discriminado

Você vai saber, sentir na pele como dói

Então aprenda a lição
Pensamos que o que mais chama a atenção nas letras de rap é verbalização de um discurso extremamente racializado, que, de um lado, demonstra a discriminação racial a que os negros estão sujeitos no dia-a-dia, e, de outro lado, constrói, reconstrói (entre os próprios rappers), desenvolve e dissemina uma consciência dessa discriminação e das desigualdades raciais que ela produz, de forma mais expressiva e expansiva (quiçá mais eficiente entre as populações da periferia) que a realizada pelos movimentos sociais negros clássicos. Ou seja, o discurso racializado do rap é uma arma que atira simultaneamente no mito da democracia racial ${ }^{6}$ brasileira e no consenso ou estratégia do silêncio sobre a questão racial no país. Mais do que isso, é uma arma que atira da periferia contra o centro do sistema. Algo consciente e intencional. Conforme afirmam, respectivamente, KlJay e Mano Brown, componentes do grupo Racionais, "Nós somos os pretos mais perigosos do país e vamos mudar muita coisa por aqui. Há pouco ainda não tínhamos consciência disso" e "Eu não sou artista. Artista faz arte, eu faço arma. Sou terrorista" (K1Jay e Mano Brown apud ShowBizz, 1998).
A mudança afirmada acima por KlJay é a 'voz ativa' dos rappers contra o racismo e as desigualdades raciais brasileiras. Mais do que isso, é a quebra do monopólio branco sobre a representação do negro no Brasil (Bairros, 1996, p. 183). O que, segundo o nosso entendimento, é semelhante ao que os negros intelectuais estão tentando realizar no campo acadêmico por meio de uma 'produção de conhecimento-pensamento ativo', conforme podese verificar em Santos (2007). Com este, busca-se a descolonização do conhecimento científico, a autonomia intelectual, a proposição de políticas de promoção da igualdade racial, bem como a quebra do controle ou monopólio dos estudos e pesquisa sobre os negros com base em um ponto de vista dos intelectuais do 'mundo dos brancos', conforme expressão cunhada por Florestan Fernandes (1972). Algo "violentamente pacífico", que "sabota o raciocínio" e "abala o sistema nervoso central" de produção do conhecimento acadêmico eurocentrado brasileiro. Algo que se expressa também nas letras das músicas dos grupos de rap, como em Voz Ativa e Capítulo 4, Versículo 3, entre outras.

6 Segundo o sociólogo Carlos Hasenbalg, "a noção de mito para qualificar a 'democracia racial' é aqui usada no sentido de ilusão ou engano e destina-se a apontar para a distância entre representação e realidade, a existência de preconceito, discriminação e desigualdades raciais e sua negação no plano discursivo" (Hasenbalg, 1996, p. 237). Noção que endossamos e utilizamos neste artigo como sinônimo de ideologia da democracia racial brasileira. 


\section{Voz Ativa}

Eu algo tenho a dizer

Explicar pra você

Mas não garanto porém

Que engraçado serei desta vez

Para os manos daqui

Para os manos de lá

Se você se considera um negro

Pra negro será

Mano!

Sei que problemas você tem demais

E nem na rua não te deixam na sua

Entre madame fudida

E racistas fardados

De cérebro atrofiado

Não te deixam em paz

Todos eles com medo generalizam demais

Dizem que os negros todos são iguais

Você concorda?

Se acomoda então

Não se incomoda em ver

Mesmo sabendo que é foda

Prefere não se envolver

Finge não ser você

Eu pergunto por que

Você prefere que o outro vá se fuder?

Não quero ser o Mandela

Apenas dar o exemplo

Não sei se você me entende

Mas eu lamento que

Eu não convivo com isso naturalmente

Não proponho ódio

Porém acho incrível

Que o nosso compromisso esteja já nesse nível

Mais

Racionais

Existente no que guarda flor dinamicamente

Manter o sal

Viva a sabedoria de rua

O F mais expressiva

A juventude negra agora tem voz ativa

Scrats

Precisamos de um líder de crédito popular

Como Malcolm X em outros tempos foi na América

Que seja negro até os ossos

Um dos nossos

E reconstrua nosso orgulho que foi feito em destro-

ços

Nossos irmãos estão desnorteados

Entre o prazer e o dinheiro

Desorientados

Brigando por quase nada

Migalhas todas banais
Capítulo 4, Versículo 3

\author{
Introdução \\ $60 \%$ dos jovens de periferia sem antecedentes criminais já \\ sofreram violência policial; \\ A cada quatro pessoas mortas pela polícia, três são negras; \\ Nas universidades brasileiras apenas dos alunos 2\% são negros; \\ A cada quatro horas um jovem negro morre violentamente \\ em São Paulo; \\ Aqui quem fala é primo preto mais um sobrevivente.?
}

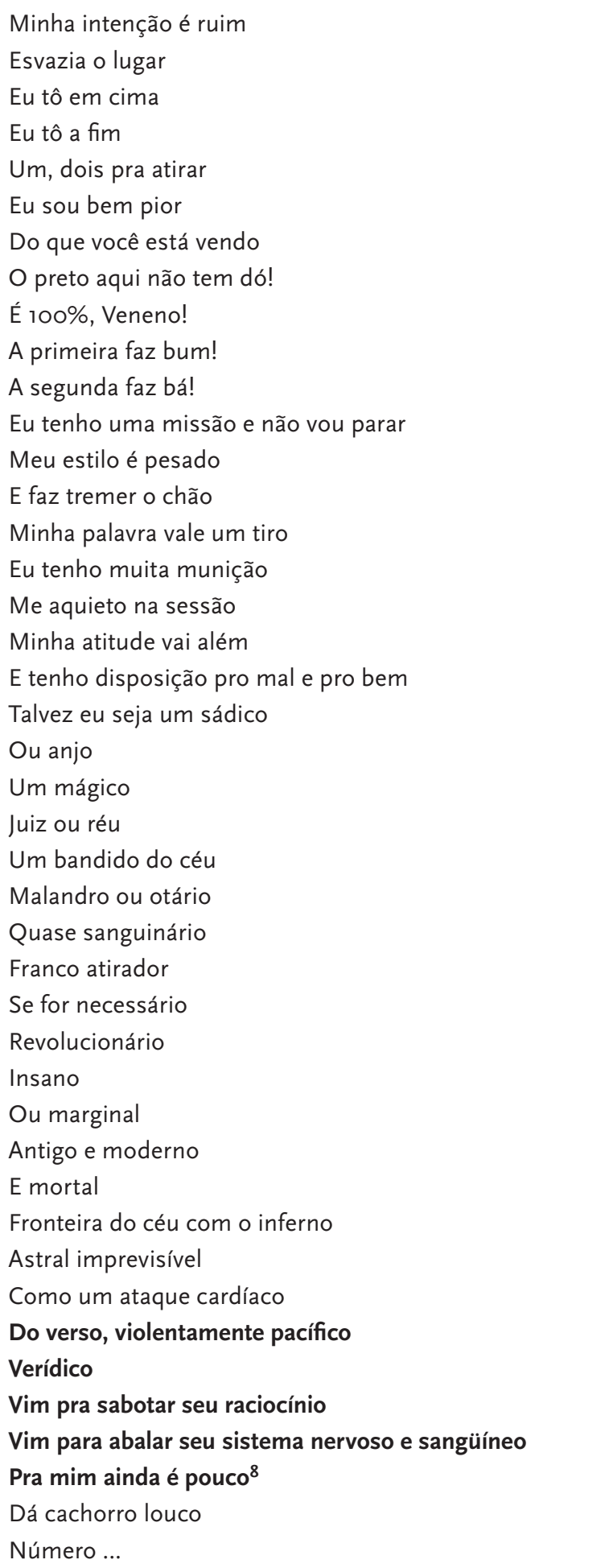

7 Grifo nosso.

8 Grifo nosso. 
Prestigiando a mentira, as falas

Desinformados demais

Chega!

De festejar a desvantagem e permitir

Que desgastem nossa imagem

Descendente negro atual

Meu nome é Brown!

Não sou complexado então

Apenas racional

É a verdade!

Mas pura postura definitiva

A juventude negra agora tem voz ativa

Scrats...

Mais da metade do país é negra

E se esquece

Que tem acesso apenas ao resto do que ele oferece

Tão pouco pra tanta gente

Tanta gente

Tanta gente na mão de tão poucos

Pode crer!

Geração iludida

Uma massa falida

De informações distorcidas e distraídas na televisão

Fudidos estão sem nenhum propósito

Diariamente assinando o seu atestado de óbito

"Pô tô cansado de toda essa merda que eles mostram na televisão todo dia mano

Não agüento mais

É foda mano!"

Mas onde estão

Meus semelhantes na tv

Nossos irmãos

Artista negro de atitude e expressão

Você se põe a perguntar por que?

Eu não sou racista

Mas meu ponto de vista

É que:

Esse é Brasil que eles querem que existe evoluído e bonito

Mas sem negro no destaque!

Eles querem mostrar um país que não existe

Escondem na Taís

Milhões de negros assistem

Engraçado que de nós eles precisam

Nosso dinheiro eles nunca discriminam

Minha pergunta que fica

Desses artistas tão famosos

Qual você se identifica?

Então:

"Leci Brandão, Moises da Rocha, Thaíde e DJ Hum, Ivo Meireles, Moleques de Rua e Tal, da Zona Leste de São Paulo: grupo DNM"

Pode crer

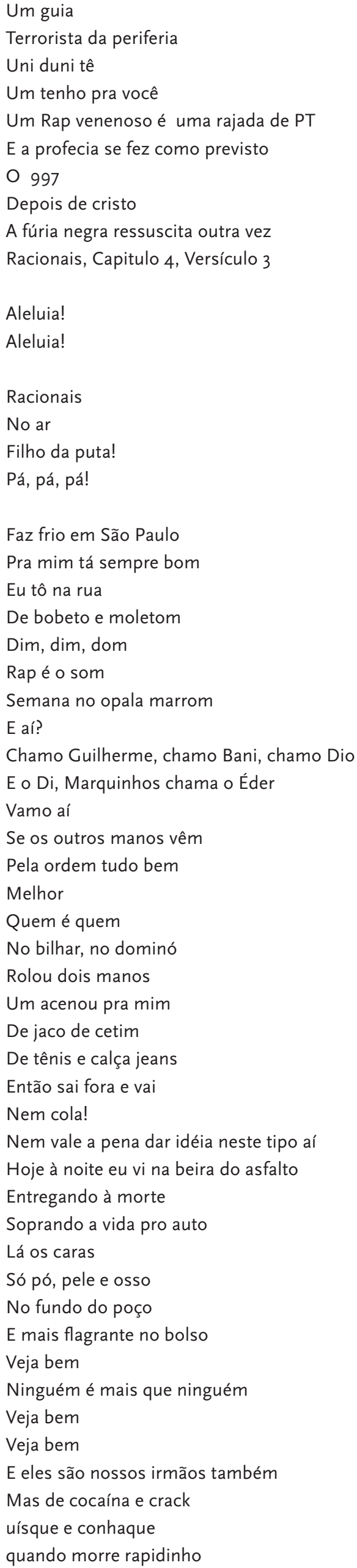

Aleluia!

Aleluia!

Racionais

No ar

Filho da puta!

Pá, pá, pá!

Faz frio em São Paulo

Pra mim tá sempre bom

Eu tô na rua

De bobeto e moletom

Dim, dim, dom

Rap é o som

Semana no opala marrom

E aí?

Chamo Guilherme, chamo Bani, chamo Dio

E o Di, Marquinhos chama o Éder

Vamo aí

Se os outros manos vêm

Pela ordem tudo bem

Melhor

Quem é quem

No bilhar, no dominó

Rolou dois manos

Um acenou pra mim

De jaco de cetim

De tênis e calça jeans

Então sai fora e vai

Nem cola!

Nem vale a pena dar idéia neste tipo aí

Hoje à noite eu vi na beira do asfalto

Entregando à morte

Soprando a vida pro auto

Lá os caras

Só pó, pele e osso

No fundo do poço

E mais flagrante no bolso

Veja bem

Ninguém é mais que ninguém

Veja bem

Veja bem

E eles são nossos irmãos também

Mas de cocaína e crack

uísque e conhaque

quando morre rapidinho 
É isso aí!

Nossos irmãos estão desnorteados

Entre o prazer e o dinheiro

Desorientados

Mulheres assumem a sua exploração

Usando o termo mulata como profissão

É mal!

Modelos brancas no destaque

As negras onde estão?

Ham!

(inaudível) no chão

Em segundo plano

Pouco original

Mas comercial a cada ano

O carnaval era a festa do povo

Era!

Mas alguns se venderam de novo

Brancos em cima

Negros em baixo

Ainda é normal

Natural

Quatrocentos anos depois

1992

Tudo igual

Bem-vindos ao Brasil colonial e tal

Precisamos de nós negros

A ser a questão

DNM meus irmãos

Escrevem com perfeição então!

Gostamos de nós

Brigamos por nós

Acreditamos mais em nós independentes do que os outros façam

Tenho orgulho de mim

O Rap em ação

Nós somos negros sim!

De sangue e coração

Mano Ice Blue me diz

Isso é que nos motiva, a minha, a sua,

A nossa Voz Ativa!

Racionais!

Racionais!

Racionais!

(scrats)
Sem lugar de destaque

Mas quem sou eu pra falar de quem cheira ou que fuma?

Nem dá!

Nunca te dei porra nenhuma!

Você fuma o que tem

Entope o nariz

Bebe tudo que vê

Faça o diabo Feliz

Você vai terminar tipo o outro mano lá

Que era um "preto tipo A"

Ninguém entrava numa

Maior estilo

De calça Calvin Klein, tênis Puma

$\mathrm{O}$ jeito humilde de ser

No toque e no rolê

Curtia um funk

Jogava uma bola

Buscava a preta dele no portão da escola

Um exemplo pra nós

Maior moral

Maior Ibope

Mas começou colar com os branquinhos do shopping

(Aí já era!)

Ih mano, outra vida

Outro pique

Só mina de elite

Balada, vários drinks

Puta de boutique

Toda aquela porra

Sexo, sem limite

Sodoma e gomorra

Faz uns nove anos

Bem uns quinze dias atrás eu vi o mano

Cê tem que ver

Pedindo cigarro

Sozinho no ponto

Dente tudo zuado

Bolso sem nenhum conto

O cara cheira mal

Assim ... a sentir medo

Muito louco de sei lá o quê

Logo cedo

Agora não oferece mais perigo

Viciado, doente e fudido

Inofensivo

Um dia um PM negro veio me passar

E disse pra eu me pôr no meu lugar

Eu vejo mano nessas condições

Não dá!

Será, assim que eu deveria estar?

Irmão o demônio fode tudo ao seu redor

Pelo rádio, jornal, revista e outdoor

Te oferece dinheiro

Conversa com calma

Contamina seu caráter

Rouba sua alma

Depois te joga na merda sozinho 
Somos "preto tipo A" meu neguinho!

Minha palavra alivia sua dor

Ilumina minha alma

Louvado seja o meu senhor

Que não deixa o mano aqui desandar

Rá!

E nem sentar o dedo em nenhum pilantra

Mas que nenhum filha da puta ignora minha lei

Racionais, Capítulo 4, Versículo 3

Aleluia!
Aleluia!
Racionais
No ar
Filho da puta!
Pá, pá, pá!

Quatro minutos se passaram e ninguém viu O monstro que nasceu em algum lugar do Brasil

Talvez o mano que trampa debaixo do carro sujo de óleo

Que enquadra o carro e fode com a pele

Com sangue nos olhos

O mano que entrega envelope o dia inteiro no sol

Ou o mano que vende chocolate de farol em farol

Talvez o cara que defende o pobre no tribunal

Ou que procura vida nova na condicional

Alguém num quarto de madeira

Lendo à luz de vela

Ouvindo um rádio velho

No fundo de uma cela

Ou da família real

E negro como eu sou

O príncipe guerreiro que defende o gol

E eu não mudo

Mas eu não me iludo

Os manos cu de burro

Bem, eu sei de tudo

Em troca de dinheiro e um carro bom

Tem mano que rebola e usa até batom

Vários patrícios falam merda

Pra todo mundo rir

Rá, rá

Pra ver branquinho aplaudir

É, na sua área tem fulano até pior

Cada um, cada um

Você se sente só

Tem mano que te aponta uma pistola e fala sério

Explode sua cara por um toca-fita velho
Plic, plau, plau, plau

E acabou!

Sem dó e sem dor!

Foda-se a sua cor

Limpa o sangue com a camisa

E manda se fuder

Você sabe por que, pra onde vai, pra que

Vai de bar em bar

De esquina em esquina

Pegar cinqüenta contos

Trocar por cocaína

Enfim o filme acabou pra você

A bala não é de festim

Aqui não tem dublê

Para os manos da Baixada Fluminense, da Ceilândia

Eu sei, as ruas não são como a Disneylândia

De Guaianeses

Nós temos sul de Santo Amaro

Ser um "preto tipo A" custa caro!

É foda!

Foda é assistir a propaganda e ver

Não dá pra ter, aquilo pra você

Play boy forgado

De brinco por trouxa

Roubado do carro na avenida Rebouças

Correntinha das moças

Madame de bolsa

Dinheiro

Não tive pai, não sou herdeiro

Se eu fosse aquele cara que se humilha no sinal

Por menos de um real

A minha chance era pouca

Mas se eu fosse aquele moleque de toca

Que engatilha e enfia o cano dentro da sua boca

De quebrada, sem roupa

Você e sua mina

Um, dois nem me viu

Já sumi na neblina

Mas não

Permaneço vivo

Sendo a mística

27 anos, contrariando a estatística

Seu comercial de tv não me engana

Rã!

Eu não preciso de status nem fama

Seu carro e sua grana já não me seduz

E nem a sua puta de olhos azuis

Eu sou apenas um rapaz Latino-americano

Apoiado por mais de cinqüenta mil manos

Efeito colateral que o seu sistema fez!

Racionais Capítulo 4, Versículo 3.
O terror expressado no discurso de Mano Brown visaria à não-resignação dos negros. Mais do que isso, visaria à negação dos negros que os brancos quiseram criar e incutir-lhes. Este 'terror' corresponde, também a uma percepção de que a pobreza tem cor; de que mesmo entre os pobres da periferia a cor/ raça faz diferença. Trata-se de um discurso que, semelhante ou igual ao dos movimentos sociais negros 
clássicos (Santos, 2007), tem como objetivo, entre outros, eliminar de uma vez por todas a ideologia da democracia racial até então amplamente difundida no Brasil, desconstruindo até mesmo o discurso acadêmico de uma parte significativa dos intelectuais brasileiros que afirma que o tratamento diferenciado entre brancos e negros se deve à distinção de classe e não de raça. Como afirmado na música Racista Otário, dos Racionais: "mas os 'sociólogos' preferem ser imparciais e dizem ser financeiro nosso dilema. No entanto se analisarmos bem mais você descobre que negros e brancos parecem, mas não são iguais" (Grifo nosso). Enfim, o terror é um discurso que ajuda a quebrar a representação do branco sobre o negro, quer na vida diária, quer no mundo acadêmico. Este terror é em realidade o que confere auto-determinação aos negros. Conforme as músicas acima e esta abaixo,

\section{Racista Otário}

Racistas otários nos deixem em paz!

Pois as famílias pobres não agüentam mais

Pois todos sabem

E elas temem

A indiferença por gente carente que se tem

E eles vêm

Com toda autoridade e preconceito eterno

E de repente o nosso espaço se transforma

Num verdadeiro inferno

E reclamar direitos de que forma

Se somos meros cidadãos

E eles o sistema

E a nossa desinformação, nosso maior problema

Mas mesmo assim,

Enfim,

Queremos ser iguais

Racistas otários nos deixem em paz!

Racistas otários nos deixem em paz!

Racistas otários nos deixem em paz!

Racistas otários nos deixem em paz!

Racistas otários nos deixem em paz!

Justiça

Em nome disso eles são pagos

Mas a noção que se tem

É limitada

E eu sei

Que a lei é implacável com os oprimidos

Tornam bandidos os que eram pessoas de bem

Pois já é tão claro que é mais fácil dizer

Que eles são os certos

E o culpado é você

Se existe ou não a culpa

Ninguém se preocupa

Em todo caso haverá sempre uma desculpa

O abuso é demais

Pra eles tanto faz

Não passará de simples fotos nos jornais

Com gente negra e carente

Não muito influente e pouco freqüente nas colunas sociais

Então eu digo

Meu rapaz

Esteja constante
Ou abrirão o seu bolso

E jogarão flagrante

Num presídio qualquer

Será um irmão a mais

Racistas otários nos deixem em paz!

Racistas otários nos deixem em paz!

Racistas otários nos deixem em paz!

Racistas otários nos deixem em paz!

Pois a lei é sempre mal interpretada

Então a velha estória outra vez se repete

Um sistema falido

Como marionetes

Nós somos movidos

E há muito tempo tem sido assim

Nos empurram à incerteza

E ao crime enfim

Porque, aí sim

Certamente estão se preparando

Com carros e armas nos esperando

Os poderosos bem seguros

Observando o rotineiro holocausto urbano

O sistema é racista, Cruel!

Levam cada vez mais

Irmãos aos bancos dos réus

Mas os sociólogos preferem ser imparciais

E dizem ser financeiro nosso dilema

Mas se analisarmos bem mais

Você descobre

Que negros e brancos parecem

\section{Mas não são iguais ${ }^{9}$}

Crianças vão nascendo em condições bem precárias

Se desenvolvendo sem a paz necessária

São filhos de pais sofridos

Por esse mesmo motivo

O nível de informação é um tanto reduzido

Não!

É um absurdo!

São pessoas assim

Que se fodem em tudo

E que no dia-a-dia vive tão insegura

E sofre as covardias

Humilhações, torturas

A conclusão é sua: KlJay 
Se julgam homens da lei

Mas a respeito eu não sei

Porém, direi para você irmãos

Nossos motivos pra lutar ainda são os mesmos

O preconceito e o desprezo ainda são iguais

Nós somos negros

Também temos nossos ideais

Racistas otários nos deixem em paz!

Racistas otários nos deixem em paz!

Racistas otários nos deixem em paz!

Racistas otários nos deixem em paz!

Racistas otários nos deixem em paz!

Os poderosos são covardes

Desleais

Estão com medo nas ruas

Por motivos banais

E nossos ancestrais por igualdade lutaram

Se rebelaram!

Morreram!

E hoje, o que fazemos?

Assistimos a tudo de braços cruzados

Até parece que nem somos nós os prejudicados

Enquanto você sossegado foge da questão

Eles circulam na rua com uma descrição

Que é parecida com a sua
Cabelo, cor, feição

Será que eles vêem em nós o marginal padrão?

Cinqüenta anos

Agora se completam da lei anti-racismo na Constitui-

ção

Infalível na teoria

Inútil no dia-a-dia

Então que foda-se eles com a sua demagogia

No meu país o preconceito é eficaz

Te cumprimentam na frente

Te dão um tiro por trás!

O Brasil é um país de clima tropical

Onde as raças se misturam naturalmente

E não há preconceito racial

Rah, rah, rah, rah, rah...

Rah, rah, rah, rah, rah...

Rah, rah, rah,...

Mas os motivos pra lutar ainda são os mesmos

O preconceito e o desprezo ainda são iguais

Nós somos negros

Também temos nossos ideais

Racistas otários nos deixem em paz!
Evidentemente, esta é uma visão de mundo de apenas um grupo de Rap Consciência do Brasil. No entanto é a visão de mundo do grupo que se tornou a referência nacional não só para os 'manos' que 'estão ligados' ao rap, mas também para outros grupos de rap, que, por sua vez, são profundamente influenciados pelo grupo os Racionais. Essa visão de mundo está sendo amplamente divulgada entre os próprios rappers, entre os grupos sociais que vivem nas periferias dos grandes centros urbanos do país e entre alguns setores da classe média brasileira, uma vez que até junho de 1998 o Racionais havia vendido mais de 250 mil cópias do seu terceiro CD (Raio X do Brasil) e mais de 500 mil do seu quarto CD (Sobrevivendo no Inferno), sem nenhuma divulgação pela mídia televisiva de grande porte ${ }^{10}$ e sem estar ligado às grandes gravadoras nacionais ou transnacionais (Caros Amigos, 1998a, 1998; ShowBizz, 1998).

Por outro lado, nem todos os grupos de rap com prestígio nacional concordam completamente com a postura ideológica dos Racionais. Para o GOG, grupo da cidade de Brasília, capital do Brasil, a questão racial não é o tema central em suas 'crônicas da periferia', que têm como foco central a denúncia da opressão social a que estão submetidos os grupos sociais vulneráveis da periferia, os pobres em geral. Entretanto, Gog, líder do grupo de mesmo nome, reconhece que é "lógico que os negros no Brasil têm muito mais problemas". Não obstante, afirma que na periferia "a bala na cabeça é tanto pro preto quanto pro branco" (Gog apud Caros Amigos, 1998, p. 21).

Porém, mesmo entre os grupos de rap de prestígio que divergem ideologicamente da postura dos Racionais quanto ao discurso racialista predominante nas letras dos Racionais, o discurso de raça e classe também é inevitável e, conseqüentemente, recorrente em suas rimas denunciantes da opressão, como se percebe na música "Brasil com P", do grupo GOG.

\section{Brasil com "P"}

Pesquisa publicada prova

Preferencialmente preto, pobre, prostituta para a polícia prender

Pare, pense, por quê? ${ }^{11}$

Prossigo,

Pelas periferias praticam perversidades,

10 Vale a pena registrar aqui a relação dos Racionais com a grande mídia televisiva, ante a visão deste grupo de rap de que a mídia televisiva é uma das grandes forças que sustentam o sistema que discrimina e oprime negros e pobres. Isto é, o poder central. Conforme a revista ShowBizz (1998, p. 29), "Televisão, nem pensar. Momentos antes de uma entrevista coletiva, em dezembro de 1997, eles (os componentes dos Racionais) gentilmente pediram aos repórteres da Globo e do SBT que se retirassem". A TV Globo é a principal rede de televisão aberta do Brasil até a presente data e o SBT, na época, era a segunda mais importante. 
PMs.

Pelos palanques políticos prometem, prometem ...

Pura palhaçada

Em proveito próprio.

Praia, programas, piscinas, palmas.

Para periferia: pânico, pólvora, pá, pá, pá ...

Primeira página,

Preço pago,

Pescoço, peito, pulmões perfurados

Parece pouco?!?

Pedro Paulo

Profissão: Pedreiro

Passa-tempo predileto: Pandeiro

Preso portando pó

Passou pelos piores pesadelos

Presídios, porões, problemas pessoais, psicológicos

Perdeu parceiros, passado, presente, pais, parentes, principais pertences

PC! Político privilegiado preso

Parecia piada!

Pagou propina pro plantão policial, passou pela porta principal

Posso parecer psicopata

E vou para a perseguição

Prevejo populares portanto pistolas

Pronunciando palavrões

Promotores públicos pedindo prisões

Pecado, pena, prisão perpétua

Palavras pronunciadas, pelo poeta irmão.

Mesmo que, de um lado, a denúncia do racismo e, de outro lado, a tentativa de construção de uma identidade racial não sejam tão enfatizadas no Rap produzido em Brasília quanto são no rap de São Paulo, conforme nos demonstra a pesquisadora Lara Amorim (1997), elas também fazem parte do repertório musical dos rappers brasilienses, conforme se pode observar na música Sub-Raça, do extinto grupo de rap brasiliense, o Câmbio Negro.

\section{Sub-Raça}

Agora irmãos vou a falar a verdade

A crueldade que fazem com a gente,

Só por nossa cor ser diferente.

Somos constantemente assediados pelo racismo cruel,

Bem pior que fel, é o amargo de engolir um "sapo",

Só por ser preto, isso é fato.

$\mathrm{O}$ valor da própria cor,

Não se aprende em faculdades ou colégios,

Que ser negro nunca foi um defeito,

Será sempre privilégio.

Privilégio de pertencer a uma raça
Que com o próprio sangue construiu o Brasil...

Sub-raça, é a puta que o pariu!!!

Sub-raça, é a puta que o pariu!!!

Sub-raça, é a puta que o pariu!!!

Sub-raça, é a puta que o pariu!!!

Sub-raça sim é como nos chamam aqueles que não respeitam as caras,

Dos filhos, dos pais, dos ancestrais deles,

Não sabem que seu bisavô, como eu, era escuro,

E obscuro será seu futuro se não agir direito,

Talvez ser encontrado em um esgoto da Ceilândia com três tiros no peito.

O papo é esse "mermo" a realidade é "foda"

Não dê um bote mal dado se não Câmbio te "bola",

Fique esperto racista se "liga na fita",

Somos "animais" "mermo" se "foda" quem não acredita.

Sub-raça, é a puta que o pariu!!!

Sub-raça, é a puta que o pariu!!!

Sub-raça, é a puta que o pariu!!!

Sub-raça, é a puta que o pariu!!!

É a puta que o pariu! Pode Crer!

É a puta que o pariu! Pode Crer!

É a puta que o pariu! Pode Crer!

Como se pode perceber, a luta afro-brasileira contra o racismo, por meio do rap, concentra-se basicamente na denúncia do racismo contra os negros, e, especialmente, na negação de uma suposta democracia racial real ou substantiva no Brasil. Nota-se, também, que essa luta é realizada por grupos que não têm 'organicidade'. Isto é, estes grupos são uma nova forma de mobilização anti-racista, mas não são estruturados como entidades negras clássicas e nem têm a mesma forma de atuação destas últimas, nem das ONGs de cunho racial. Eles instrumentalizam a música para denunciar o racismo contra os afro-brasileiros. É uma forma de luta difusa, que não carece de um grupo de militantes anti-racismo organizado formalmente por meio de instituições ou de reuniões (semanais ou mensais) ordinárias e extraordinárias, visando a discutir e deliberar sobre a questão racial ou mesmo estabelecer relações/interações com o Estado brasileiro para combater o racismo no país. Carece menos ainda de líderes orgânicos que se vêem e são vistos/reconhecidos como líderes e representantes políticos dos afro-brasileiros ${ }^{12}$.

Ao contrário dos movimentos sociais negros clássicos, que sempre tentaram conquistar um lugar no espaço público, os músicos do Rap Consciência não parecem ter esse propósito. Eles estão à margem e falam, ou melhor, cantam posicionados da margem (ou da pe- 
riferia) contra o centro do sistema. Ao que tudo indica, esta nova forma de luta afro-brasileira, em termos de discurso, não busca a negociação da questão racial no espaço público. Querem o fim da opressão racial, que o centro do poder, por meio do racismo e outros tipos de violência, tem imposto à margem. Conseqüentemente, pregam a união interna entre os membros da periferia e a agressão ao poder central do sistema, como forma de defesa. Dessa forma, eles contribuem de uma maneira bem particular na luta anti-racismo dos movimentos sociais negros, embora não se pareça com nenhuma das formas de luta negra descritas em Santos (2007).

\section{Conclusão}

Assim, considerando-se as formas de luta afro-brasileira no pós-abolição, podemos perceber que elas vêm não somente se ampliando e ampliando suas conquistas, mas também vêm apresentando novas nuanças a ponto de, nesse momento, já podermos falar em lutas afrobrasileiras no plural. Todas elas a cumprirem um de- terminado papel, nem mais nem menos importante, no combate ao racismo. Mais do que isso, todas as formas de luta contra o racismo quer por meio dos movimentos sociais negros clássicos, de ONGs negras, parlamentares negros, negros intelectuais (Santos, 2007), quer por meio dos rappers e do Rap Consciência que vimos neste artigo, entre outras formas, vêm contribuindo para negar o discurso do branco sobre o negro ou para "quebrar o monopólio branco sobre a representação do negro no Brasil" (Bairros, 1996); monopólio que historicamente vinha colocando as lutas e as reivindicações dos afro-brasileiras à margem do espaço público.

Portanto, a atuação de novos agentes sociais antiracismo, como os parlamentares negros engajados na luta anti-racismo, as ONGs de cunho racial, os negros intelectuais (Santos, 2007), os rappers e seu instrumento de luta, qual seja, o Rap Consciência, entre outros, associada à luta histórica dos movimentos sociais negros clássicos, não só colocaram a discussão da questão racial na agenda política e/ou pública brasileira (Santos, 2007), mas também consolidaram como ponto de pauta nesta agenda a histórica reivindicação dos movimentos sociais negros por igualdade formal e substantiva para a população negra brasileira.

\section{Referências}

AMORIM, Lara Santos de. Cenas de uma revolta urbana: Movimento hip hop na periferia de Brasília. Dissertação (Mestrado em Antropologia)-Universidade de Brasília/ Departamento de Antropologia (DAN), Brasília, 1997.

ANDREWS, George Reid. Negros e Brancos em São Paulo (1888-1988). Bauru/São Paulo: Edusc, 1998.

O protesto político negro em São Paulo - 1888 1998. Estudos Afro-Asiáticos, v. 21, p. 27-48, dez. de 1991. BAIRROS, Luiza. Orfeu e Poder: uma perspectiva afroamericana sobre a política racial no Brasil. Afro-Ásia, v. 17, p. 173-186, 1996.

DAMASCENO, Caetana de [et al] (Orgs.). Catálogo de Entidades de Movimento Negro no Brasil. Rio de Janeiro: ISER, 1988.

CAROS AMIGOS. Ed. n. 3, Setembro/1998.

EXECUTIVA NACIONAL DA MARCHA ZUMBI

(ENMZ). Por uma política nacional de combate ao racismo e à desigualdade racial: Marcha Zumbi contra o racismo, pela cidadania e vida. Brasília: Cultura Gráfica e Editora, 1996.

FERNANDES, Florestan. O negro no mundo dos brancos. São Paulo: Difusão Européia do Livro, 1972.

HASENBALG, Carlos A. Entre o mito e os fatos: racismo e relações raciais no Brasil. In: MAIO, Marcos Chor; SANTOS, Ricardo Ventura (Orgs.). Raça, Ciência e Sociedade. Rio de Janeiro: FIOCRUZ/CCBB, 1996.

. Discriminação e desigualdades raciais no Brasil. Rio

de Janeiro: Graal, 1979.

MOURA, Clóvis. A dialética radical do Brasil negro. São Pau- lo: Editora Anita, 1994.

MUNANGA, Kabengele. Identidade, cidadania e democracia: algumas reflexões sobre os discursos anti-racistas no Brasil. In: SPINK, Mary Jane Paris. A cidadania em construção. Uma reflexão transdisciplinar. São Paulo: Cortes, 1994.

PINHO, Osmundo de Araújo. Revolução afrodescendente do século XXI. Tempo e Presença. v. 319, p. 17-20, set. de 2001.

SANTOS, Hélio. Uma avaliação do combate às desigualdades raciais no Brasil. In: GUIMAR ÃES, Antonio Sérgio Alfredo; HUNTLEY, Lynn. Tirando a Máscara. Ensaios sobre o racismo no Brasil. São Paulo: Paz e Terra, 2000.

SANTOS, Sales Augusto dos. Movimentos negros, educação e ação afirmativa. Tese (Doutorado em Sociologia) - Brasília: UnB, jun. de 2007.

SHOWBIZZ, Ed. 155, jun. 1998.

\section{Discografia}

CÂMBIO NEGRO. Sub-Raça. Discovery, 1998.

GOG. CPI da Favela. Zâmbia Fonográfica, 2000.

RACIONAIS MC'S. Sobrevivendo no Inferno. Cosa Nostra Fonográfica, 1997.

Raio X do Brasil. Zimbabwe Records, 1993. 


\title{
The Rappers and the 'Conscious Rap': New Agents and Instruments in the Struggle against Racism in 1990's Brazil
}

\begin{abstract}
An important change for black people mobilization against racism in Brazil in the1990s was the re-utilization of music, by means of rap music, as a way to denounce and condemn Brazilian racial oppression. In this article, I intend to show how an important part of Afro-Brazilians rappers, who, until then, did not directly participate in the struggle against racism, have now started to fight racism together with classical black social movements, using their music as an instrument against racism.
\end{abstract}

Key words: Rap; rappers; struggle against racism; Black Social Movements.

Data de recebimento do artigo: 19-05-2008

Data de aprovação do artigo: 28-08-2008 